\title{
Diel variations in bacterioplankton, phytoplankton, and related parameters in the Southern California Bight
}

\author{
Jed A. Fuhrman ${ }^{1}$, Richard W. Eppley ${ }^{2}$, Åke Hagström ${ }^{3}$ \& Farooq Azam ${ }^{2}$ \\ ${ }^{1}$ Marine Sciences Research Center, State University of New York, Stony Brook, New York 11794, USA \\ ${ }^{2}$ Institute of Marine Resources, A-018, Scripps Institution of Oceanography, University of California, San Diego, La Jolla, \\ California 92093, USA \\ ${ }^{3}$ Department of Microbiology, University of Umeå, S-901 87 Umeå, Sweden
}

\begin{abstract}
The principal objectives of this study were (i) to determine the extent of coupling between phytoplankton and microheterotrophs on the shelf off Southern California, (ii) to compare different measures of primary and bacterial secondary production, and (iii) to assess whether sampling times should be as strictly controlled for microheterotroph as for autotroph studies. Two diel cycles (May and October) were studied by sampling an isotherm as the ship followed paired submerged drogues. We found significant diel changes of chlorophyll, ${ }^{14} \mathrm{C}$ bicarbonate incorporation, bacterial abundance and thymidine incorporation, frequency of dividing bacterial cells (FDC), abundance of non-pigmented flagellates, particulate organic carbon and nitrogen and their ratios, and dissolved oxygen. These parameters all had higher values during daylight hours than at night, showing close coupling between the phytoplankton (light-forced) and the microheterotrophs. The ratio of in vivo to extracted chlorophyll a fluorescence, however, displayed a maximum at midnight and minimum at midday, suggesting an endogenous rhythm. Primary production measured by the ${ }^{14} \mathrm{C}$ method was similar to net production inferred from in situ oxygen changes. Short-lived peaks in FDC values suggested partly synchronized bacterial division.
\end{abstract}

\section{INTRODUCTION}

Day-night (diel) cycles of biological and related parameters in the ocean are primarily a manifestation of the relation between sunlight and the marine biota. Our interest in studying these cycles is based on both questions about nature and practical considerations. The recent discovery that heterotrophic bacterioplankton can consume up to $60 \%$ of the total pelagic primary production (Hagström et al. 1979, Fuhrman \& Azam 1980, 1982, Williams 1981) has led to particular interest in the relations between phytoplankton and bacteria. The routes by which fixed carbon becomes dissolved and available to bacteria are known to include direct release from photosynthesizing phytoplankton (e.g. Larsson \& Hagström 1982), 'sloppy feeding' by zooplankton (Lampert 1978, Copping \& Lorenzen 1980, Eppley et al. 1981), and release from detritus, but the relative importance of these routes is unknown. An important factor is the time scale of the coupling between phytoplankton and bacteria. This can be investigated by examining diel cycles because tight coupling (i.e. with time scales of minutes to hours) would result in significant diel variations of bacterial activity in response to varying photosynthesis.

A practical aspect of studying diel cycles involves optimum sampling times. It is obvious that rates of photosynthesis vary throughout the day and it is therefore necessary to choose sampling and incubation times carefully for primary productivity measurements. It is not so obvious, however, whether sampling and incubation times are as important for measurements of bacterial activity. Constrained by the expense of ship time, most previous studies of the distribution of bacterial biomass and activity at sea (e.g. Ferguson \& Palumbo 1979, Fuhrman et al. 1980) have taken samples whenever the ship arrived on station rather than waiting for a particular time of day for 'comparable' measurements.

Previous diel studies have taken 3 basic approaches: 
(1) samples are contained and subsampled over time (cf. Eppley et al. 1971); (2) sampling occurs in 1 geographical location (e.g. anchored ship, beach) over time (cf. LeBouteiller \& Herbland 1982); or (3) some attempt is made to follow a water parcel and it is sampled over time (cf. Ryther et al. 1971). Each approach has advantages and disadvantages. Containment has the advantage that there is no doubt that the same water is being subsampled over time, but there is the disadvantage of not knowing if the contained water is representative of natural water. Important organisms may be too rare or can evade capture. So-called 'bottle effects' can substantially alter the make-up of the contained populations within hours to days (Venrick et al. 1977, Ferguson et al. 1984). Very large containers (mesocosms) are probably better than smaller ones in these regards.

Sampling at 1 geographical position (e.g. MeyerReil et al. 1979) has the advantage of dealing with truly natural samples and is fairly easy to perform, but there is the disadvantage that water may flow past the sampling location, and different populations may be sampled at different times (Ferguson \& Palumbo 1979). This may be particularly pronounced in a tidally influenced region, where apparent repeating patterns ( 6 or $12 \mathrm{~h}$ periodicities) could be mistaken for diel variations in a single population.

Following a natural parcel of water with time has the advantage that the same planktonic populations are sampled and there are no containment artifacts. Disadvantages are that it requires knowledge of the physics of water parcels and some means of following the water (i.e. a drogue and a ship). Admittedly, conceptual problems arise because it is not clear to what extent a parcel to water remains a single entity over time as it is turbulently mixed with adjacent water (discussed later). Nevertheless, we believe this is the best approach currently available, and it is the one we have used.

\section{MATERIALS AND METHODS}

Experiments were performed on 8 to 9 May and 3 to 4 October, 1981, from the research vessel R/V New Horizon' in a moderately oligotrophic region of the Southern California Bight approximately $6 \mathrm{~km}$ offshore with approximately 100 to $500 \mathrm{~m}$ water depth (see Fig. 1). Two cruciform drogues, each $1.5 \mathrm{~m}$ high $\times 2 \mathrm{~m}$ wide, constructed of polyvinyl chloride and nylon and suspended on polypropylene line between 2 small plastic floats and a concrete weight, were deployed ca $100 \mathrm{~m}$ apart. The depths of deployment were chosen from CTD casts; in May the drogues were in the thermocline $(21 \mathrm{~m})$ and in October they were at the base of the surface mixed layer (10 m; Fig. 2).

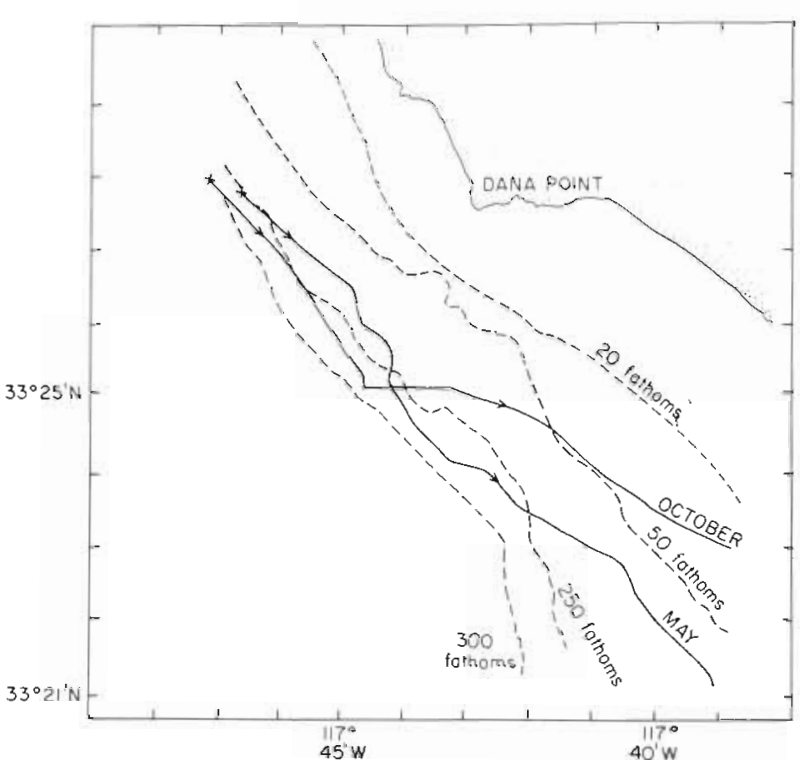

Fig. 1. Map of study area and drogue tracks

The sampling strategy was to follow the drogues with the ship and periodically lower a CTD rosette system equipped with several specially cleaned 5 I Niskin bottles. Samples were taken by filling the bottles at the isotherm corresponding to the initial temperature at the drogue deployment depth. In this way we hoped to continue sampling the same water parcel even in the presence of internal waves. On the May cruise, 2 bottles were closed (at least $10 \mathrm{~s}$ apart) at each time point and the 2 water samples were independently analyzed. On that cruise we also filled an acidwashed and copiously rinsed $20 \mathrm{l}$ polyethylene carboy with seawater from extra Niskin bottles closed at the initial sampling. The carboy was kept on deck, covered with blue plastic to simulate the in situ light level $(12 \%$ of surface) in flowing surface seawater for temperature control. Samples from the carboy were drawn and treated in parallel to those from the ocean.

Standard methods were used for biological and physical properties. Conductivity, temperature, and depth were measured with a Plessey model 9040 CTD probe. In vivo chlorophyll fluorescence was determined (October only) with a Sea Mar Tech model 6000 submersible fluorometer, and in addition to profiling, the system was set to record the fluorescence at the instant the sample bottles were filled. Nutrients were analyzed by standard wet chemistry techniques, and extracted chlorophyll a (on Whatman GF/C filters) by fluorometry, corrected for phaeopigments (Strickland \& Parsons 1972). Dissolved oxygen was measured by micro Winkler titrations (Carpenter 1965). Particulate organic carbon (POC) and nitrogen (PON), collected on $\mathrm{GF} / \mathrm{C}$ filters, were determined according to Sharp (1974) on a Hewlett Packard CHN analyzer. Primary 

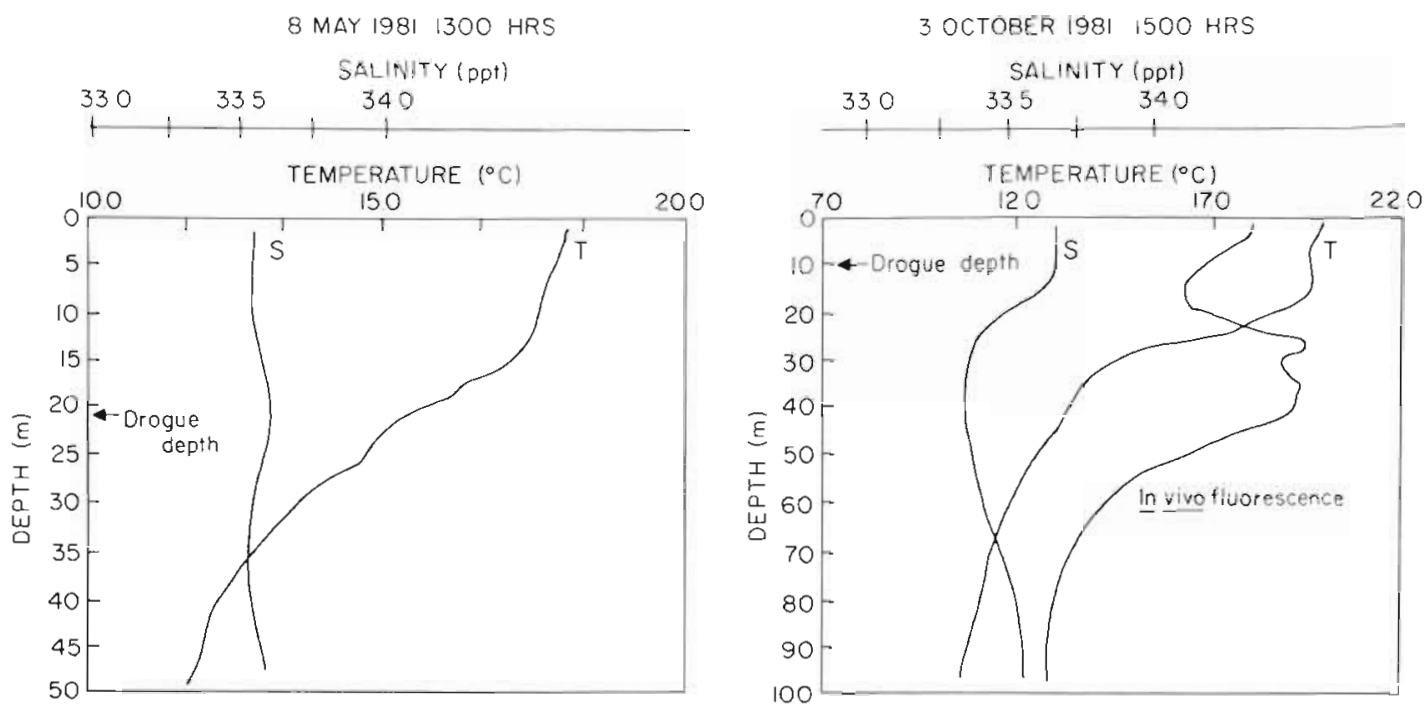

Fig. 2. CTD profiles and associated fluorescence trace. Note the near-surface structure in the October fluorescence profile (arbitrary units) even where the temperature and salinity suggest that the water is well-mixed

production was measured under simulated in situlight (neutral-density screens) by the ${ }^{14} \mathrm{C}$ technique following Strickland \& Parsons (1972), on $200 \mathrm{ml}$ samples pre-screened through $183 \mu \mathrm{m}$ Nitex mesh; no dark bottles were used, and particulate material was collected by gentle vacuum filtration onto GF/C filters which were rinsed with ca $2 \mathrm{ml}$ of filtered seawater before measurement of radioactivity by liquid scintillation. Bacterial abundance was determined at sea (within a day of sampling) in May by acridine orange direct epifluorescence counts (Hobbie et al. 1977). In October, samples were counted within a few days of return to the laboratory, and ethidium bromide was the fluorescent stain; these same slides were used for determination of the frequency of dividing bacterial cells (Hagström 1984) and abundance of non-pigmented flagellates (flagellates with red chlorophyll autofluorescence were not counted). The incorporation rate of tritiated thymidine into trichloroacetic acidinsoluble material was measured as in Fuhrman \& Azam (1982).

\section{RESULTS}

In each experiment, the drogue pairs traveled together in a southeasterly direction, with final separations between drogues of less than a few hundred meters, compared to the drogue track length of about $16 \mathrm{~km}$. The May and October drogue tracks were very similar to each other (Fig. 1).

The physical characteristics of the upper water column were also similar in the May and October experiments. The CTD casts showed that the May drogues, deployed at $21 \mathrm{~m}$, stayed within well-stratified water (Fig. 2). Although it appeared from physical data alone that the October drogues, deployed at $9.5 \mathrm{~m}$, were at times in water that mixed to the surface, the submersible fluorometer data suggest that if mixing occurred near the drogues, vertical layering of chlorophyll-containing particles was reestablished within a few hours.

Our attempts to sample at an isotherm were generally successful, despite the difficulties of getting a sample bottle, suspended from a rolling ship, to close in water of a particular temperature. In May, the temperature of sampled water was $15.0 \pm 0.3^{\circ} \mathrm{C}$, and in October, it was $19.5 \pm 0.1^{\circ} \mathrm{C}$.

The nutrient levels and light penetration showed that the sampling region was moderately oligotrophic (Table 1). The $1 \%$ light depth was approximately 35 to

Table 1. Initial nutrient concentrations, micromolar

\begin{tabular}{|lrrrr|}
\hline Study & Ammonium & Nitrate & Phosphate & Silicate \\
\hline May & 0.1 & 0.06 & 0.26 & 4.4 \\
October & $<0.1$ & 0.04 & 0.29 & 2.6 \\
\hline
\end{tabular}

$45 \mathrm{~m}$. The other experimental data, summarized in Fig. $3 \& 4$, suggest that most of the biological parameters had higher values during daylight than at night.

Statistical information on the variability between duplicate bottle samples (May) shows that the coefficients of variation ranged from $0.4 \%$ for oxygen to $16.4 \%$ for ${ }^{14} \mathrm{C}$ bicarbonate uptake (Table 2). Similar variability may be expected for the October data, although duplicate bottle samples were not collected then. 


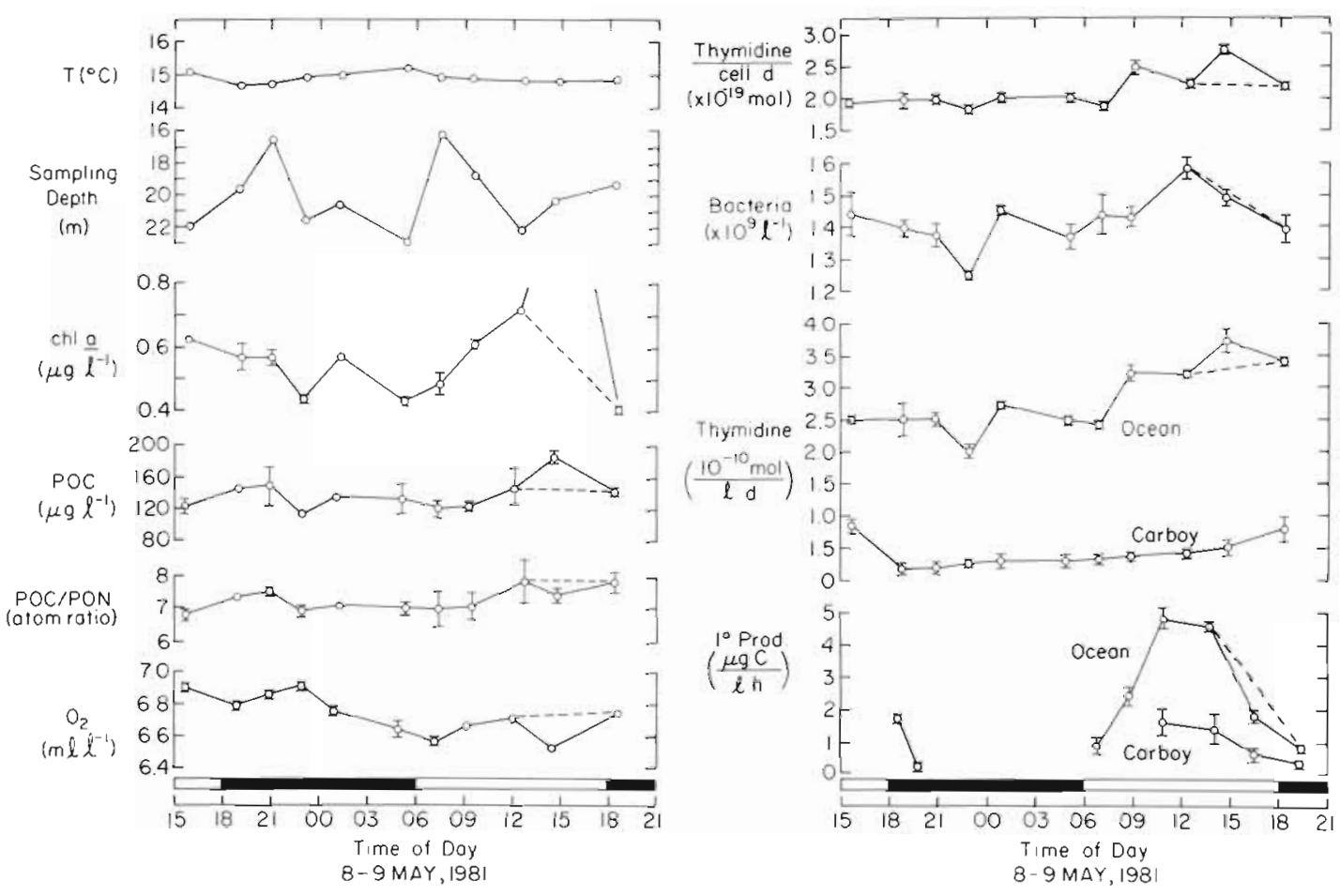

Fig. 3. Time courses of measured parameters in May. Error bars represent range of duplicate Niskin bottles. Oxygen saturation concentration was $5.74 \mathrm{ml} \mathrm{l}^{-1}$. For broken lines, see text
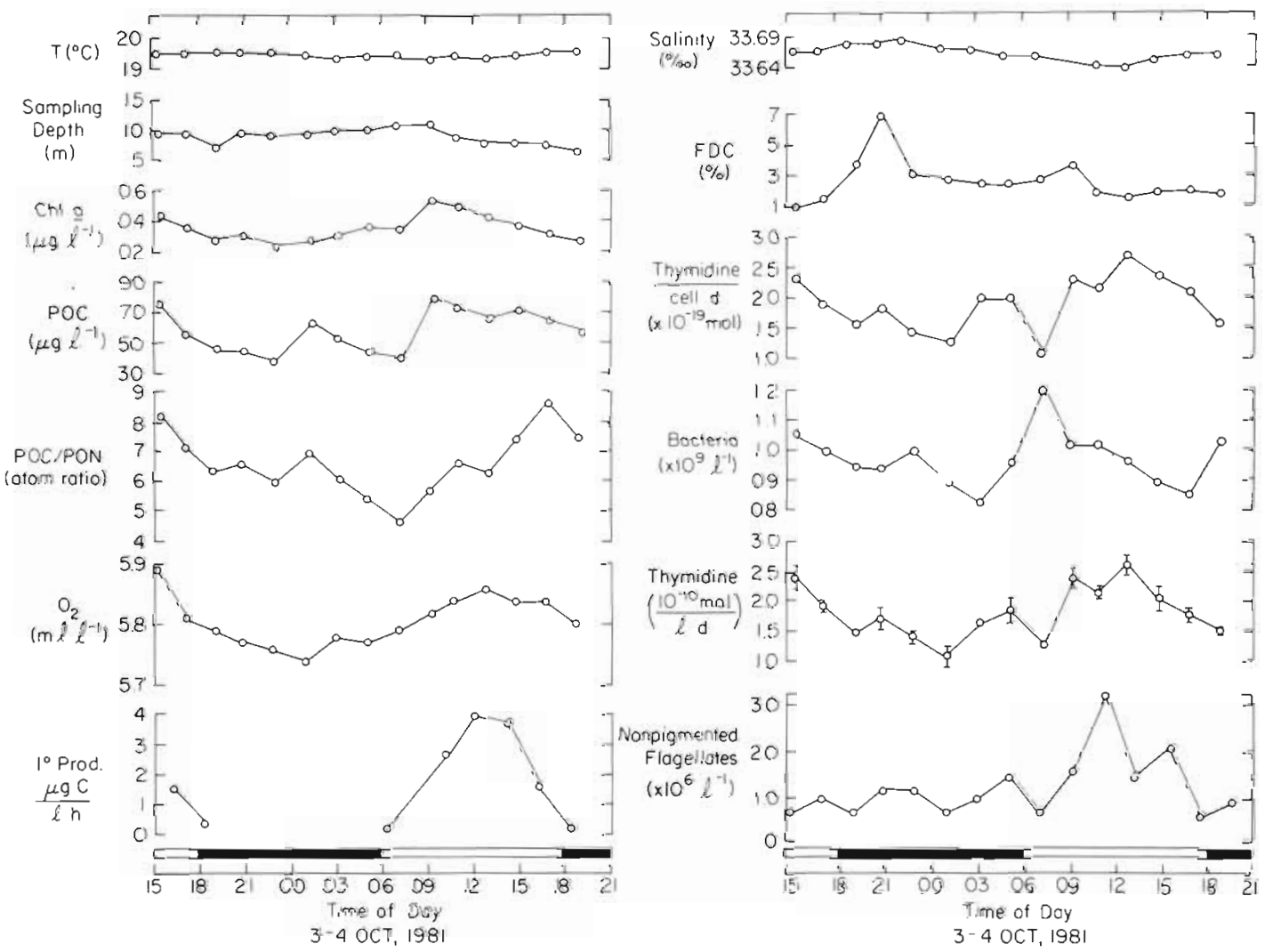

Fig. 4. Time courses of measured parameters in October. Error bars on thymidine incorporation represent range of duplicate subsamples from the same Niskin bottle. Oxygen saturation concentration was $5.27 \mathrm{ml} 1^{-1}$ 
Table 2. Coefficients of variation (CV) for duplicate determinations (separate Niskin bottles) on May cruise

\begin{tabular}{|lc|}
\hline Parameter & Average CV \\
\hline Chlorophyll a & $4.2 \%$ \\
POC & $12.3 \%$ \\
PON & $9.7 \%$ \\
Oxygen & $0.4 \%$ \\
Thymidine incorp. & $4.9 \%$ \\
Bacterial counts & $2.8 \%$ \\
${ }^{14}$ C bicarbonate uptake & $16.3 \%$ \\
\hline
\end{tabular}

\section{DISCUSSION}

\section{Physical considerations}

Our goal in this study was to subsample a natural plankton population over at least 1 diel cycle and measure various characteristics related to the biomass and productivity of the phytoplankton and bacterioplankton. We followed drogues in an attempt to minimize aliasing of our data which could occur when sampling from the vertically and horizontally patchy marine environment. Our physical data show that the water we collected had very similar temperature and salinity over time. If we had sampled at drogue depths instead of isotherms, internal waves moving water up and down past the drogues would have provided water of very different properties at different times; in May we had to adjust the sample depths between 23 and $16 \mathrm{~m}$ in order to sample an isotherm (Fig. 3). However, because we followed the drogues, which were deployed at fixed depths, but the water we were interested in was at variable depth, it is possible that different current velocities at different depths (shear) caused the drogue to mislead us (see Winant \& Bratkovich 1981, for this region). We cannot completely discount this possibility, but note that the 2 different drogue tracks (May and October) were very similar even though the May drogues were at $21 \mathrm{~m}$ in the thermocline and the October drogues were at $9.5 \mathrm{~m}$. It is also encouraging that even though the bottom shoaled over time in both experiments, the plankton properties showed no marked changes associated with it.

The fact that the pairs of drogues traveled together in both experiments, and separated by only a few hundred meters over a path length of more than $16 \mathrm{~km}$, leads us to believe that we were sampling a reasonably stable and coherent patch of water. It is probably safe to say that the water we subsampled came from a volume with a horizontal diameter of 0.5 to $1 \mathrm{~km}$ or less and a depth of 2 to $3 \mathrm{~m}$ or less.

One sample, from 1500 h on 9 May, seemed to have anomalously high chlorophyll and low dissolved oxygen values, even though the temperature was normal. We suspect that at this sample time, the ship was positioned improperly relative to the drogues (probably due to drift in the wind), and the sampler reached into the edge of the chlorophyll maximum layer (thus the dashed lines in Fig. 3). Unless otherwise noted, we will assume that at the other times we sampled from a single population and will discuss the results accordingly, but we do realize that some of the observed differences may be due to sampling different patches.

Patchiness on the meter scale could potentially add noise to our data. The relatively small coefficients of variation between duplicate bottle samples in May (compared to changes with time; Table 2 and Fig. 3) show that this problem was minor. However, $20 \%$ differences between the properties of 2 bottles filled within a few seconds of each other occurred for some parameters. Thus, the 'noisier' parameters, such as POC and ${ }^{14} \mathrm{C}$ bicarbonate uptake had to change by at least a few 10 's of percent over time to show a measurable diel cycle.

\section{Diel patterns - qualitative aspects}

\section{Phytoplankton}

It is obvious that primary production should have a pronounced diel cycle, with carbon fixation occurring only during daylight hours. This was of course reflected in the ${ }^{14} \mathrm{C}$ incorporation data. One might also expect photosynthesis to lead to a diurnal increase in the dissolved oxygen, and this, too was observed (see specific discussion of oxygen below).

The chlorophyll data, indicating phytoplankton biomass, also might be expected to follow a generally sinusoidal pattern, with growth dominating in the day and grazing at night (LeBouteiller \& Herbland 1982). This pattern was generally found, in that highest chlorophyll concentrations were found during the day, and lowest at night.

An interesting feature of the chlorophyll data of October was a strong diel cycle in the ratio of in vivo to extracted chlorophyll a fluorescence (Fig. 5). This ratio

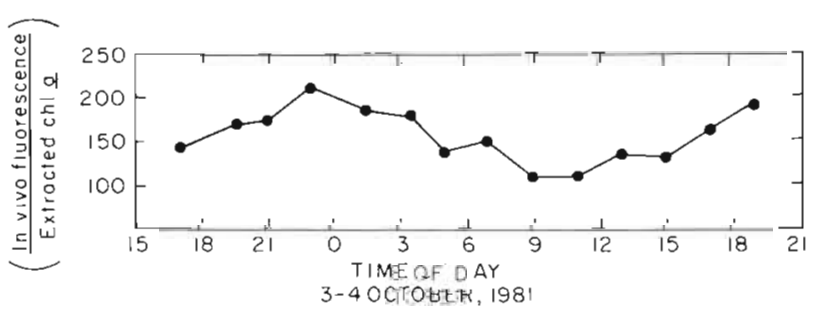

Fig. 5. Time course of the ratio of in vivo to extracted chlorophyll a fluorescence in Octaber. Units are arbitrary 
was highest near midnight and lowest in late morning. Such a periodicity has been seen before by Kiefer (1973), Prezélin \& Ley (1980) and Setser et al. (1982) in ocean samples. In the latter report, the diel change in the fluorescence/extracted chlorophyll was limited to the equatorial upwelling portion of their transect and was absent in the oligotrophic waters at its boundaries. Owens et al. (1980) noted periodicity in the ratio of extracted to in vivo chlorophyll fluorescence in a laboratory culture but it was absent in their field experiments. Comparisons of extracted chlorophyll with fluorescence recorded by a moored in situ fluorometer showed, however, a diel periodicity perhaps related to our observations.

This ratio is probably related to one or a combination of the following: (1) the organization (including shape) of the thylakoid membranes or chloroplasts, (2) the concentration of quinone-type quenchers within the phytoplankton, and (3) energy transfer between accessory pigments and chlorophyll a (Prezélin \& Ley 1980, Owens et al. 1980). The fact that the ratio peaked near midnight and dropped through the rest of the dark period suggests that it is controlled at least in part by an endogenous rhythm (cellular 'clock'), and not just light levels alone (cf. Brand 1982).

Phytoplankton usually make up about one-third of the POC (Eppley et al. 1977), but it is hard to find a diel pattern in the May POC data, especially given the poor replicability of this parameter (Table 2). The October results show a stronger diel pattern (except for an increase after midnight). Probably more significant than the POC values alone were the particulate C:N ratios. On both cruises, this ratio was highest during the day and lowest near dawn. This is probably the result of differential patterns of $\mathrm{C}$ and $\mathrm{N}$ uptake by phytoplankton - namely, $\mathrm{CO}_{2}$ is fixed only during daylight, but $\mathrm{N}$ is taken up both day and night.

\section{Bacterioplankton}

In this study, we found pronounced diel patterns of both bacterial abundance and growth rate estimates On both cruises, the bacterial abundance was highest during the day and lowest at night; in May, the peak was near noon, and October it was shortly after dawn Thymidine incorporation, a measure of heterotrophic bacterial production (Fuhrman \& Azam 1982), was also higher during the day than at night; in October it very closely paralleled the primary production and concentrations of chlorophyll and dissolved oxygen. This implies a close relation, or tight coupling, between the phytoplankton and bacterioplankton, with bacterial production closely following primary production. Note that the thymidine incorporation per bacterial cell, an index of bacterial specific growth rates, also was higher in the day than at night. This means that the diurnal increase in total thymidine incorporation was not just because there were more bacteria; on average, each cell grew faster during the day.

Previous studies also demonstrated diel cycles of bacteria, with higher biomass or rate measurements during daytime. This has been found in coastal waters (Sieburth et al. 1977, Meyer-Reil et al. 1979, Hagström \& Larsson 1984), simulated ecosystems (Burney et al. 1981), the open ocean (Burney et al. 1982, Johnson et al. 1983), and water overlying coral reefs (Moriarty et al. 1985). Carlucci et al. (1984) reported higher amino acid metabolism rates during the day than at night in our samples; this generally coincides with our observed pattern of bacterial production rates discussed here. Other workers, though, found only small or inconsistent (unpredictable) diel patterns; such was observed for bacterial secondary production by Riemann \& Sondergaard (1984) at a Danish coastal marine station and in 5 lakes, and by Riemann et al. (1984) at the coastal station.

There are a few possible explanations for the tight coupling between primary production and bacterial growth apparent in our samples. One mechanism by which photosynthate becomes dissolved and available to bacteria is the release of dissolved material from photosynthesizing phytoplankton. Another related but separate mechanism is the loss of algal cell contents during grazing by herbivores ('sloppy feeding'). There is also DOC release by the herbivores and release from fecal matter or other detritus.

Tight coupling between phytoplankton and bacteria as we have observed would seem to favor DOC sources close to the original primary production, because as more steps are added between carbon fixation and bacteria, more lags and less coupling would be expected. Thus, first on the list of probable DOM source mechanisms would be release from healthy algae. A pattern such as we observed would be expected if leakage is a positive function of the production rate (i.e. more leakage at higher production rates).

For 'sloppy feeding' by macrozooplankton to cause the observed patterns, it would require more grazing during the day. This is contrary to what is expected given that macrozooplankton are believed to largely migrate out of the lighted surface waters during the day and return at night. Little is known about grazing and 'sloppy feeding' by microzooplankton, and it is possible that these processes occur more during the day than at night (e.g if the microzooplankton themselves are grazed by macrozooplankton at night and thus graze more during the day in the relative absence of predators). The arguments about 'sloppy feeding' 
probably also apply to other zooplankton-mediated DOM source mechanisms, such as excretion. We can think of no reason why decay of detritus, as a DOM source, should be greater during the day than at night. Thus it seems that the most likely mechanism leading to the tight coupling between phytoplankton and bacteria is leakage from intact phytoplankton, but grazing effects from microzooplankton may also be important. Calculations (see below) are consistent with this hypothesis.

Variations in growth rate alone cannot explain the variations in bacterial abundance; loss terms must also be considered. Increases in bacterial abundance result from growth exceeding losses, and decreases result from the opposite. Loss terms for the bacteria are not well known, but the prevalent viewpiont is that grazing by Protozoa, most likely microflagellates, is the most important factor (Fenchel 1982, Azam et al. 1983, Fuhrman \& McManus 1984).

The morning increases in bacterial abundance are probably due to increased growth (higher DOM flux). The afternoon and evening abundance losses may be due to increased grazing by the microflagellates (see below). Thus it appears that the DOM supply rate starts increasing early in the morning, and this stimulates bacterial growth. Grazers probably catch up with the bacteria by afternoon, and higher grazing plus lowered DOM flux lead to afternoon and evening declines in bacterial abundance.

\section{Flagellates}

The October data (Fig. 4) appear to show a diel cycle of abundance of non-pigmented flagellates with a peak in late morning following the bacterial peak. We note that the flagellate peak is from a single high point in late morning. In fact, the sharp rise in abundance between 0700 and $1100 \mathrm{~h}$ suggests more than 2 doublings in $4 \mathrm{~h}$, which seems unreasonably high. However, even if the $1100 \mathrm{~h}$ measurement was too high by a factor of 2, 4 of the 5 highest abundance values would still be during the day, suggestive of a diel cycle.

As the cells counted were not chlorophyll-containing, they are probably heterotrophic phagotrophs, grazing on bacteria (however, it should be noted that at least some pigmented forms readily consume bacteria; Fenchel 1982). Their higher daytime abundance suggests growth outstrips death (presumably grazing by larger protozoa and other zooplankton) early in the day. This could either be due to an increase in their own bacterial ingestion rates, a decrease in the rate at which they are grazed, or both. Their daytime bacterial ingestion rates could be higher because the bacteria are more abundant then (by about $25 \%$ ), and at a constant filtering rate, higher prey (bacterial) abundance translates into a higher ingestion rate. Their daytime mortality rates could be less if some or all of their predators vertically migrate downward at dawn (i.e. macrozooplankton). Probably both factors occur to some extent, but more work is needed on the subject. It is even possible that some of the flagellates themselves underwent small vertical migrations, influencing our results.

\section{Oxygen}

The diel changes in oxygen concentration, in a closed system, should represent a superposition of oxygen production by photosynthesis and consumption by respiration. The system here is not closed, however, and as with other measured properties, some of the observed changes may be due to either mixing or sampling different patches of water. Although we cannot completely discount these latter effects, it is encouraging to note that in October the oxygen concentrations followed a smooth sinusoidal curve with a maximum near noon and a minimum near midnight; this shape is close to that of many of the biological parameters. Also, a close examination of the October data revealed that oxygen varied by $80 \%$ of its entire diel range among 5 samples with nearly identical salinities (of these, salinities were $33.666 \pm .002 \mathrm{ppt}$ and oxygen concentrations were $5.83 \pm .06 \mathrm{ml} \mathrm{l}^{-1}$ ). This observation, plus the fact that the quantitative changes in oxygen concentrations were in the range expected from other biological rate measurements (see below), leads us to believe that it is appropriate to attempt interpretation of the oxygen changes from a biological point of view.

In May, the oxygen concentration also decreased at night and tended to increase during the day (the increase is clearer if the $1500 \mathrm{~h}$ time point is ignored, as we suggested earlier). Thus it appeared that there was positive net production through the day and negative net production (respiration) at night, as one might expect. In October, however, losses seemed to start in the afternoon and last until early morning, and positive net production occurred only up to about noon. There was also a small unexpected increase in oxygen between midnight and dawn, but this was apparently in the range of sampling and measurement error (means \pm 1 SD from Table 2 would barely overlap), unlike the larger overall diel changes. The unexpected oxygen decreases in the afternoons in October does not necessarily imply faulty measurements. Positive net community production need not last throughout the daylight period just because gross primary production occurs then. The time of the maximum oxygen concentration depends on the timing of the diel cycles of 
both primary production and community respiration. Note that we observed a daytime peak in bacterial activity (thymidine incorporation) and heterotrophic flagellate abundance. The recent observation that microheterotrophs are major oxygen consumers (Williams 1981) thus suggests that a daytime community respiration peak could be expected. Overall, the October data are consistent with the hypothesis that community respiration was greater during the day than at night, and that it exceeded oxygen production in the afternoon and night.

\section{Quantitative comparison of results}

\section{Primary production}

One goal of this study was to compare the results of different methods that measure related processes. Of particular interest is the estimation of primary productivity, which has recently become the subject of controversy (see Smith et al. 1984). It is believed that the ${ }^{14} \mathrm{C}$ method measures something between the gross and net primary production, because some of the labeled carbon fixed during the incubation can be respired by algae as well as consumers (see Williams et al. 1983, Smith et al. 1984). A different estimate of primary production is from changes in dissolved oxygen, either in bottle samples or in the natural or seminatural environment (Antia et al. 1963, Smith \& Marsh 1973, Tijssen 1979); this method should measure the net community primary production because production and respiration respectively generate and consume oxygen along with fixed carbon. Thus it is expected that production estimated from the ${ }^{14} \mathrm{C}$ technique should exceed those from net changes in dissolved oxygen (ignoring considerations of DOM release, discussed below).

A comparison of oxygen and carbon estimates of production requires knowing the photosynthetic quotient ( $\mathrm{PQ}$, moles $\mathrm{O}_{2}$ evolved/moles $\mathrm{CO}_{2}$ fixed). Using balanced equations of growth, $\mathrm{PQ}$ can be calculated to be 1.1 for growth on ammonium and 1.45 for growth on nitrate (for Chlorella, from Myers 1949 cited in Morris 1981, cf. Burris 1981, Williams et al. 1983). We have used a value of 1.25 as an educated guess.

An unbiased way of calculating the net production or consumption rates from changes in oxygen is to use a linear regression of increasing or decreasing concentrations as an estimate, respectively. Choice of the data to include in the regression is critical. An obvious choice would be to look for increases during daylight and decreases during darkness. This seems appropriate for the May experiment, where there were general nocturnal decreases and diumal increases, but it may not be for October, because at that time there appeared to be net oxygen consumption in both afternoons. Thus, we used diurnal increases and nocturnal decreases in May, and for October we used net respiration from the 1st through 8th sample points (afternoon to dawn) and net production between the 8th and 12th sampling points (dawn and midday). The estimates from these regressions are given in Table 3 , along with the integrated carbon production estimates from ${ }^{14} \mathrm{C}$ measured over the same time periods. These ' $\mathrm{raw}{ }^{14} \mathrm{C}$ production estimates were lower in May and higher in October than those from oxygen changes; in both experiments, the 2 estimates were within about $10 \%$ of each other (not significantly different).

One of the complicating factors in interpreting these data is that all primary production does not remain in particulate form - some fraction becomes dissolved through a variety of processes (direct release, sloppy feeding, etc.). Thus, measurement of ${ }^{14} \mathrm{C}$ appearance on particles somewhat underestimates the carbon production. However, estimates based on dissolved oxygen changes are not affected. The ${ }^{14} \mathrm{C}$ method can be modified to include estimates of labeled DOC production, and previous studies have generally found that about 5 to $25 \%$ of the total fixed labeled carbon is dissolved (Berman \& Holm-Hansen 1974, Williams \& Yentsch 1976, Larsson \& Hagström 1982). These values were probably underestimates because some of the ${ }^{14} \mathrm{C}$ labeled DOM is respired back to $\mathrm{CO}_{2}$ after bacterial uptake. Attempts to correct this by a time-course approach (Lancelot 1979) have shown that an average of $25 \%$ (though up to $62 \%$ ) of the production can be dissolved.

Adding $25 \%$ to our estimates, as a rough correction for DOC release, would make the May ${ }^{14} \mathrm{C}$ estimate about $111 \%$ of the estimate from oxygen changes, and the October ${ }^{14} \mathrm{C}$ value would be about $133 \%$. Thus these adjusted rates are in accordance with the expectation that the ${ }^{14} \mathrm{C}$ estimate should be higher than that from oxygen, but given the statistical uncertainties of

Table 3. Primary production and net oxidation rate estimates, $\mu g \mathrm{Cl}^{-1} \mathrm{~h}^{-1}$

\begin{tabular}{|c|c|c|c|c|}
\hline \multirow[t]{2}{*}{ Method } & \multicolumn{2}{|c|}{ May } & \multicolumn{2}{|c|}{ October } \\
\hline & $\begin{array}{l}\text { Produc- } \\
\text { tion }\end{array}$ & $\begin{array}{l}\text { Con- } \\
\text { sumption }\end{array}$ & $\begin{array}{l}\text { Produc- } \\
\text { tion }\end{array}$ & $\begin{array}{l}\text { Con- } \\
\text { sumption }\end{array}$ \\
\hline${ }^{14} \mathrm{C}^{*}$ & 2.92 & - & 1.78 & - \\
\hline $\begin{array}{l}\text { Oxygen } \\
\text { change }\end{array}$ & $3.29(.87)$ & $4.88(.90)$ & $1.67(.99)$ & $1.42(.53)$ \\
\hline \multicolumn{5}{|c|}{$\begin{array}{l}\text { - Integrated from dawn to dusk in May, and } 0520 \text { to } 1300 \\
\text { h in Oct (same hours as linear regressions for oxygen) } \\
\text { - } \text { From linear regressions. Numbers in parentheses are } \mathrm{r}^{2} \\
\text { values from linear regressions (see text for details) }\end{array}$} \\
\hline
\end{tabular}


the ${ }^{14} \mathrm{C}$ rates (average $\mathrm{CV}$ of duplicates $=16.3 \%$, Table 2), the 2 estimates are not very different.

It should be stressed that these comparisons are quite tentative. Physical mixing and surface ventilation could have influenced the oxygen levels in 1 or both time series, despite our precautions. Also, we assumed 'typical' values for $\mathrm{PQ}$ and $\mathrm{DOC}$ release that significantly influenced the results; other possible combinations of $\mathrm{PQ}$ and release values could have made both the 'adjusted' ${ }^{14} \mathrm{C}$ values lower than those from oxygen changes. Probably the safest conclusion is that the ${ }^{14} \mathrm{C}$ and oxygen estimates were comparable. Thus we have no evidence that the ${ }^{14} \mathrm{C}$ method grossly underestimates primary production, but the nature of our data precludes more quantitative conclusions.

We made 1 additional comparison of ${ }^{14} \mathrm{C}$ primary productivity methods between a single $27 \mathrm{~h}$ incubation and several back-to-back incubations of a few hours each. In previous studies (e.g. Eppley \& Sharp 1975, Gieskes et al. 1979), the shorter incubations yielded higher rates. This has been ascribed to respiration by both phytoplankton and heterotrophs of the ${ }^{14} \mathrm{C}$ label, and also to unknown containment artifacts. In contrast to these previously published studies, our May experiment showed nearly identical rates for a single $27 \mathrm{~h}$

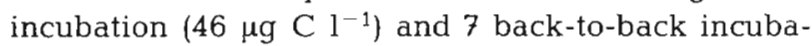
tions ranging from 1 to $4.7 \mathrm{~h}$ each (total for $27 \mathrm{~h}$ of 46.7 $\mu \mathrm{g} \mathrm{C}^{-1}$ ). Thus the difference between short and long ${ }^{14} \mathrm{C}$ incubations need not be great.

In addition to the production estimates discussed above, Table 3 shows estimates of net organic matter consumption (oxidation) rates calculated from the nocturnal decline of dissolved oxygen. The oxygen data suggested a net consumption of organic matter in May and net production in October, using a PQ of 1.25 and a respiratory quotient of 1.

\section{Bacterial heterotrophic production}

A rough calculation (assuming $10 \mathrm{fg} \mathrm{C}$ bacterium $^{-1}$; Fuhrman 1981) indicates that the average bacterial production rates estimated from thymidine incorporation were equivalent to about $16 \%$ of the total particulate primary production rates (from the ${ }^{14} \mathrm{C}$ results) in May, and $15 \%$ in October. At an assumed $50 \%$ bacterial gross growth efficiency, this would require 30 to $32 \%$ of the average $24 \mathrm{~h}$ particulate primary production to reach the bacteria, and the diel changes would require a variation of about 20 to $42 \%$ of the average primary production; the percentage of daytime production alone would be about half of these values. This calculation indicates that our hypothesis of phytoplankton release controlling bacterial diel production cycles fits with known release rates.
These experiments permit evaluation of methods for measuring bacterial production. First, we compare net changes of bacterial abundance to production estimates by thymidine incorporation and FDC. Analogous to the ${ }^{14} \mathrm{C}$ approach, the thymidine incorporation method probably measures something between the bacterial population growth rate (growth minus grazing) and the gross bacterial growth rate (specific growth rate times abundance), because grazing during the incubation may lower some of the incorporated radioactivity. Thus, net changes in abundance (population growth rate) should be lower than production estimates from thymidine incorporation. The FDC approach is different in that it requires no incubation, and it thus ideally measures the gross bacterial growth rate. Therefore the FDC-calculated rates should be higher than those from thymidine incorporation. Short incubations for thymidine incorporation should minimize the difference.

Table 4 shows that these expected relations hold. It is not clear if the relatively large difference between the FDC-and thymidine-calculated rates is solely due to grazing effects during the thymidine incubation or partly due to differences in the accuracy of the methods. If the former factor is the most important, the large difference would suggest very rapid grazing of bacteria and respiration of the label - probably more rapid than recent grazing estimates would suggest (Fenchel 1982, Fuhrman \& McManus 1984). Thus it seems probable that the difference is attributable in part to methodological inaccuracies. Each method has its own calibration and potential problems.

FDC is calibrated with continuous cultures of mixed marine bacterial populations growing at a known dilution rate and temperature (Hagström et al. 1979, Hagström 1984). However, natural production rates may be overestimated because the calibration cultures select for bacteria all of the same growth rate, but such

Table 4. Comparison of increases in bacterial abundance and production estimates $\left(\right.$ all $\times 10^{8}$ cells $\left.\mathrm{l}^{-1} \mathrm{~d}^{-1}\right)$

\begin{tabular}{|lcc|}
\hline Method & May & October \\
\hline Increase in bacterial abundance & 3.3 & 3.5 \\
Thymidine incorporation * & $4.4-8.3$ & $2.4-5.9$ \\
FDC. & - & $12.6-27$ \\
& \\
- Uses a conversion factor of $2.3 \times 10^{18}$ cells produced \\
per mole thymidine incorporated (Fuhrman \& Azam \\
1982) \\
Calculated from Southern California continuous cul- \\
tures as in Hagström et al. (1979). Excludes the peak at \\
2100 h which is probably the result of synchronized \\
division. Equation: FDC $=21.2 \mu+$ 0.5 (Hagström \\
1984), calibrated at $20^{\circ} \mathrm{C}$ \\
\hline
\end{tabular}


uniform activity probably does not occur in nature. The FDC results (Fig. 4) illustrate another important factor which complicates interpretation of FDC data, namely synchronized growth. The evidence for this is the large peak in FDC at $2100 \mathrm{~h}$ and smaller one at $0900 \mathrm{~h}$. The FDC measurement is good enough to resolve these peaks; Hagström et al. (1979) report that the FDC measurement is accurate to within $0.5 \% \mathrm{FDC}$ or better, and Hagström \& Larsson (1984) show that the coefficient of variation for replicate FDC measurements is typically below $20 \%$. Thus, even the smaller peak, at 1 to 2 percentage points above its neighbors, is probably significant. A certain degree of synchronization of division may be expected when growth rates increase and decrease with a regular pattern, as was shown here by the regular diel pattern of thymidine incorporation.

Usually, FDC is interpreted assuming no synchronization of growth. Significant synchronization, as we and Hagström \& Larsson (1984) observed, means that single FDC determinations are of limited use - a measurement made at the peak of division would greatly overestimate production while ones made at other times would underestimate production. However, the average of a large number of FDC measurements made throughout the day, as was done here, should give a production estimate unaffected by synchronization. Note that the peak of FDC need not coincide with the peak in bacterial biomass production - it can occur before or after it.

Peaks in FDC probably represent significant events in the microbial community, given that at those times a relatively large portion of the bacteria are dividing. The timing of the two peaks, $12 \mathrm{~h}$ apart, roughly corresponds to the $10 \mathrm{~h}$ average generation time calculated from the average FDC value. At this time, however, we do not know what environmental factors control the apparent synchronization.

The production estimates from thymidine incorporation can also under- or overestimate production. The method has been calibrated by 2 different approaches (Fuhrman \& Azam 1982), one involving incorporation into a purified DNA fraction, measurement of bacterial DNA content, and estimation of intracellular isotope dilution, and the second involving the empirical relation between thymidine incorporation and growth of 'seawater cultures' (Ammerman et al. 1984). Both methods show some variability of the calibration, and statistical analysis shows that previous production estimates were probably within a factor of 2 of the true values, when used in Southern California coastal waters (Fuhrman \& Azam 1982). Certain types of calibrations in different waters have sometimes found 'conversion factors' larger than that used here (Kirchman et al. 1982, Ducklow \& Hill 1985), while others have determined essentially the same factor (BeIl et al.
1983, Moriarty et al. 1985); it is not known if variations are from differences in the calibration methods or bacterial populations in the different areas.

Examination of the October results (Fig. 4) suggests that the thymidine estimates here may be low - the bacterial abundance change between 0300 and $0800 \mathrm{~h}$ displays a production rate of nearly $2 \times 10^{9} \mathrm{cells}^{-1}$ $\mathrm{d}^{-1}$, faster than the thymidine-calculated rates, but within the range of the FDC-calculated values. This could mean that the FDC-calculated rates are more realistic, but it may be unreasonable to make such a sweeping conclusion from a single particularly high abundance value at $0800 \mathrm{~h}$. Newell \& Fallon (1982) also noted that in samples from Georgia coastal waters, FDC-calculated production rates were higher than those from thymidine incorporation, but they could not be certain which method gave the most accurate measurement. Hagström (1984) reported good agreement between FDC and thymidine production estimates for coastal California waters. At any rate, the thymidine estimate with the original 'conversion factor' remains a conservative one, as was originally intended.

Overall, then, the bacterial data suggest that the average FDC values may have provided a more realistic estimate of gross bacterial production than did the thymidine incorporation results, but both methods gave values greater than the bacterial abundance changes. However, partial synchronization of bacterial division made it difficult to make conclusions from individual FDC measurements. Furthermore, the thymidine data most clearly showed the diel pattern of bacterial production, with daytime highs being more than $50 \%$ higher than nighttime lows.

\section{Carboy experiment}

The contained 20 I sample had very different properties compared to freshly-collected natural samples (Fig. 3). The ${ }^{14} \mathrm{C}$ bicarbonate uptake rates in both were very similar the first afternoon $\left(0.175 \pm .005 \mu \mathrm{gC} \mathrm{l} \mathrm{l}^{-1}\right.$ $\mathrm{h}^{-1}$ fresh vs $0.155 \pm .005$ carboy), but on the next day, the subsamples from the carboy had only about onethird the activity of the fresh samples. The thymidine uptake was apparently immediately inhibited; the first carboy sample had only $40 \%$ of the activity of the fresh one, and the later carboy samples even less. By the second afternoon, the thymidine uptake increased slightly, but it did not even reach its initial inhibited level.

We suspect that there was some sort of a contaminant, possibly trace metals, in the carboys or one of the 'extra' Niskin bottles used to fill them. Whatever it was, it had a quicker and more pronounced effect on bacteria than phytoplankton. This is indirect evidence 
that bacteria could be more susceptible to inadvertent inhibitory contamination than phytoplankton (cf. Ferguson \& Sunda 1984).

In conclusion, we found this approach for measuring diel cycles a useful way of examining coupling between different planktonic organisms. Some of our results were similar to those reported by others, and some different. We cannot say to what extent these differences were due to variations in methodologies as opposed to differences in the plankton populations studied. We have been able to shed light on some current methodologies, but questions still remain. Further studies of this type, with newer techniques and better precision, can probably answer some of these questions.

Acknowledgements. We thank E. Renger, J. Ammerman, A. Neori, C. Price, N. Cooper, S. Horrigan, D. Long, Dr. A. Carlucci, Dr. M. Mullin, other Food Chain Research Group personnel, and the captain and crew of the R/V 'New Horizon' for their help with these experiments. This work was supported by DOE contract \# DE-AT03-82-ER-60031.

\section{LITERATURE CITED}

Ammerman, J. W., Fuhrman, J. A., Hagström, §., Azam, F. (1984). Bacterioplankton growth in seawater: I. Growth kinetics and cellular characteristics in seawater cultures. Mar. Ecol. Prog. Ser. 18: 31-39

Antia, N. J., McAllister, C. O., Parsons, T. R., Stephens, K., Strickland, J. D. H. (1963). Further measurements of primary production using a large-volume plastic sphere. Limnol. Oceanogr. 8: 166-183

Azam, F., Fenchel, T., Field, J. G., Gray, J. S., Meyer-Reil, L. A., Thingstad, F. (1983). The ecological role of watercolumn microbes in the sea. Mar. Ecol. Prog. Ser. 10: $257-263$

Bell, R. T., Ahlgren, G. M., Ahlgren, I. (1983). Estimating bacterioplankton production by measuring $\left[{ }^{3} \mathrm{H}\right]$ thymidine incorporation in a Swedish lake. Appl, environ. Microbiol. 45: 1709-1721

Berman, T., Holm-Hansen, O. (1974). Release of photoassimilated carbon as dissolved organic matter by marine phytoplankton. Mar. Biol. 28: 305-310

Brand, L. E. (1982). Persistent diel rhythms in the chlorophyll fluorescence of marine phytoplankton species. Mar. Biol. 69: 253-262

Burney, C. M., Davis, P. G., Johnson, K. M., Sieburth, J. McN. (1981). Dependence of dissolved carbohydrate concentrations upon small scale nanoplankton and bacterioplankton distributions in the western Sargasso Sea. Mar. Biol. 65: 289-296

Burney, C. M., Davis, P. G., Johnson, K. M., Sieburth, J. McN. (1982). Diel relationship of microbial trophic groups and in situ dissolved carbohydrate dynamics in the Caribbean Sea. Mar. Biol. 67: 311-322

Burris, J. E. (1981). Effects of oxygen and inorganic carbon concentration in the photosynthetic quotients of marine algae. Mar. Biol. 65: 215-219

Carlucci, A. F., Craven, D. B., Henrichs, S. M. (1984). Diel production and microheterotrophic utilization of dissolved free amino acids in waters off southern California. Appl. environ. Microbiol. 48: 165-170

Carpenter, J. H. (1965). The Chesapeake Bay Institute technique for the Winkler dissolved oxygen method. Limnol. Oceanogr. 10: 141-147

Copping, A. E., Lorenzen, C. J. (1980). Carbon budget of a marine phytoplankton-herbivore system with carbon-14 as a tracer. Limnol. Oceanogr. 25: 873-882

Ducklow, H. W., Hill, S. M. (1985). Tritiated thymidine incorporation and the growth of heterotrophic bacteria in warm core rings. Limnol. Oceanogr. 30: 260-272

Eppley, R. W., Carlucci, A. F., Holm-Hansen, O., Kiefer, D., McCarthy, J. J., Venrick, E., Williams, P. M. (1971). Phytoplankton growth and composition in shipboard cultures supplied with nitrate, ammonium, or urea as the nitrogen source. Limnol. Oceanogr. 16: 741-751

Eppley, R. W., Harrison, W. G., Chisholm, S. W., Stewart, E. (1977). Particulate organic matter in surface waters off Southern California and its relationship to phytoplankton. J. mar. Res. 35: 671-696

Eppley, R. W., Horrigan, S. G., Fuhrman, J. A., Brooks, E. R., Price, C. C.. Sellner, K. (1981). Origins of dissolved organic matter in Southern Califomia coastal waters: experiments on the role of zooplankton. Mar. Ecol. Prog. Ser. 6: 149-159

Eppley, R. W., Sharp, J. H. (1975). Photosynthesis measurements in the central North Pacific: the dark loss of carbon in 24-hour incubations. Limnol. Oceanogr. 20: 981-987

Fenchel, T. (1982). Ecology of heterotrophic microflagellates. IV. Quantitative occurrence and importance as bacterial consumers. Mar. Ecol. Prog. Ser. 9: 35-42

Ferguson, R. L., Buckley, E. N., Palumbo, A. V. (1984). Response of marine bacterioplankton to differential filtration and confinement. Appl. environ. Microbiol. 47: 49-55

Ferguson, R. L., Palumbo, A. V. (1979). Distribution of suspended bacteria in neritic waters south of Long Island during stratified conditions. Limnol. Oceanogr. 24: $697-705$

Ferguson, R. L., Sunda, W. G. (1984). Utilization of amino acids by planktonic marine bacteria: importance of clean technique and low substrate additions. Limnol. Oceanogr. 29: $258-274$

Fuhrman, J. A. (1981). Influence of method on the apparent size distribution of bacterioplankton cells: epifluorescence microscopy compared to scanning electron microscopy. Mar. Ecol. Prog. Ser, 5: 103-106

Fuhrman, J. A., Azam, F. (1980). Bacterioplankton secondary production estimates for coastal waters of British Columbia, Antarctica, and California. Appl. environ. Microbiol. 39: 1085-1095

Fuhrman, J. A., Azam, F. (1982). Thymidine incorporation as a measure of heterotrophic bacterioplankton production in marine surface waters: evaluation and field results. Mar. Biol. 66: 109-120

Fuhrman, J. A., McManus, G. B. (1984). Do bacteria-sized marine eukaryotes consume significant bacterial production? Science 224: 1257-1260

Fuhrman, J. A., Ammerman, J. W., Azam, F. (1980). Bacterioplankton in the coastal euphotic zone: distribution, activity, and possible relationships with phytoplankton. Mar. Biol. 60: 201-207

Gieskes, W. W. C., Kraay, G. W., Baars, M. A. (1979). Current ${ }^{14} \mathrm{C}$ methods for measuring primary production: gross underestimates in oceanic waters. Neth. J. Sea Res. 13: 58-78

Hagström, $\AA$. (1984). Aquatic bacteria: measurements and significance of growth. In: Klug, M. J., Reddy, C. A. (ed.) 
Current perspectives in microbial ecology. Amer. Soc Microbiol., Washington DC., p. 495-501

Hagström, À., Larsson, U. (1984). Diel and seasonal variation in growth rates of pelagic bacteria. In: Hobbie, J. E. Williams, P. J. leB. (ed.) Heterotrophic activity in the sea. Plenum Press, New York, p. 249-262

Hagström, §., Larsson, U., Horstedt, P., Normark, S. (1979). Frequency of dividing cells, a new approach to the determination of bacterial growth rates in aquatic environments. Appl. environ. Microbiol. 37: 805-812

Hobbie, J. E., Daley, R. J., Jasper, S. (1977). Use of Nuclepore filters for counting bacteria by fluorescence microscopy. Appl. environ. Microbiol. 33: 1225-1228

Johnson, P. M., Davis, P. G., Sieburth, J. McN. (1983). Diel variation in $\mathrm{TCO}_{2}$ in the upper layer of oceanic waters reflects microbial composition, variation, and possibly methane cycling. Mar. Biol. 77: 1-10

Kirchman, D., Ducklow, H., Mitchell, R. (1982). Estimates of bacterial growth from changes in uptake rates and biomass. Appl. environ. Microbiol. 44: 1296-1307

Kiefer, D. A. (1973). Fluorescence properties of natural phytoplankton populations. Mar. Biol. 22: 263-269

Lampert, W. (1978). Release of dissolved organic carbon by grazing zooplankton. Limnol. Oceanogr. 23: 831-834

Lancelot, C. (1979). Gross excretion rates of natural marine phytoplankton and heterotrophic uptake of excreted products in the Southern North Sea, as determined by shortterm kinetics. Mar. Ecol. Prog. Ser. 1: 179-186

Larsson, U., Hagstrom, $\AA$. (1982). Fractionated phytoplankton primary production, exudate release and bacterial production in a Baltic eutrophication gradient. Mar. Biol. 67 $57-70$

LeBouteiller, A., Herbland, A. (1982). Diel variation of chlorophyll a as evidenced from a 13-day station in the equatorial Atlantic Ocean. Oceanologica Acta 5: 433-441

Meyer-Reil, L.-A., Bölter, M., Liebezeit, G., Schramm, W. (1979). Short-term variations in microbiological and chemical parameters. Mar. Ecol. Prog. Ser. 1: 1-6

Moriarty, D. J. W., Pollard, P. C., Hunt, W. G. (1985). Temporal and spatial variation in bacterial production in the water column over a coral reef. Mar. Biol. 85: 285-292

Morris, I. (1981). Photosynthetic products, physiological state, and phytoplankton growth. In: Platt, T. (ed.) Physiological bases of phytoplankton ecology. Can. Bull. Fish. Aquat. Sci. \# 210, p. 83-102

Myers, J. (1949). The pattern of photosynthesis in Chlorella. In: Franck, J., Loomis, W. E. (ed.) Photosynthesis in plants. Am. Soc. Plant. Physiol., Iowa State College Press, Ames, p. 349-364

Newell, S. Y., Fallon, R. D. (1982). Bacterial productivity in the water column and sediments of the Georgia (USA) coastal zone: estimates via direct counting and parallel measurement of thymidine incorporation. Microb. Ecol. 8: $33-46$

Owens, T. G., Falkowski, P. G., Whitledge, T. E. (1980). Diel periodicity in cellular chlorophyll content of marine diatoms. Mar. Biol. 59: 71-77
Prezélin, B. B., Ley, A. C. (1980). Photosynthesis and chlorophyll a fluorescence rhythms of marine phytoplankton. Mar Biol. 55: 295-307

Riemann, B., Søndergaard, M. (1984). Measurements of diel rates of bacterial secondary production in aquatic environments. Appl. environ. Microbiol. 47: 632-638

Riemann, B., Nielsen, P., Jeppesen, M., Marcussen, B., Fuhrman, J. A. (1984). Diel changes in bacterial biomass and growth rates in coastal environments, determined by means of thymidine incorporation into DNA, frequency of dividing cells (FDC), and microautoradiography. Mar. Ecol. Prog. Ser. 17: 227-235

Ryther, J. H., Menzel, D. W., Hulburt, E. M., Lorenzen, C. J., Corwin, N. (1971). Production and utilization of organic matter in the Peru coastal current. Anton Bruun Rep. No. 4, Texas A \& M Press, College Station

Setser, P. J., Guinasso, N. L., Jr., Schink, D. R. (1982). Daily patterns of fluorescence in vivo in the central equatorial ocean. J. mar. Res. 40: 453-471

Sharp, J. H. (1974). Improved analysis for 'particulate' organic carbon and nitrogen from seawater. Limnol. Oceanogr. 19: 984-989

Sieburth, J. McN, Johnson, K. M., Burney, C. M., Lavoie, D. M. (1977). Estimation of in situ rates of heterotrophy using diurnal changes in organic matter and growth rates of picoplankton in diffusion culture. Helgoländer Meeresunters. 30: 565-574

Smith, S. V., Marsh, J. A., Jr. (1973). Organic carbon production on the windward reef flat of Eniwetok Atoll. Limnol. Oceanogr. 18: 953-961

Smith, R. E., Geider, R. J., Platt, T. (1984). Microplankton productivity in the oligotrophic ocean. Nature, Lond. 311 : 252-254

Strickland, J. D. H., Parsons, T. R. (1972). A practical handbook of seawater analysis. 2nd ed. Bull. Fish. Res. Bd Can. 167

Tijssen, S. B. (1979). Diurnal oxygen rhythm and primary production in the mixed layer of the Atlantic Ocean at 20 N. Neth. J. Sea Res. 13: 79-84

Venrick, E. L., Beers, J. R., Heinbokel, J. F. (1977). Possible consequences of containing microplankton for physiological rate measurements. J. exp. mar. Biol. Ecol. 26: 58-76

Williams, P. J. leB. (1981). Incorporation of microheterotrophic processes into the classical paradigm of the planktonic food web. Kieler Meeresforsch. (Sonderh.) 5: 1-28

Williams, P. J. leB., Heinemann, K. R., Marra, J, Purdie, D. A. (1983). Comparison of ${ }^{14} \mathrm{C}$ and $\mathrm{O}_{2}$ measurements of phytoplankton production in oligotrophic waters. Nature, Lond. 305: 49-50

Williams, P. J. leB., Yentsch, C. S. (1976). An examination of photosynthetic production, excretion of photosynthetic products, and heterotrophic utilization of dissolved organic compounds with reference to results from a coastal subtropical sea. Mar. Biol. 35: 31-40

Winant, C. D., Bratkovich, A. W. (1981). Temperature and currents on the southern California shelf: a description of the variability. J. phys. Oceanogr. 11: 71-86 